UNITED STATES DEPARTMLNT OF AGRICULTURE

Agrioul tural Research Administration

Bureau of Pintomology and Plant Quarantine Washington 25, D. C.

October 23, 1950

B.E.P.Q. 574, Supploment No. 1

PLANT QUARANTINE IMPORT RESTRICTIONS

OF THE NETHERLANDS

IMPORTATION OF WOODY PLANTS RESTR ICTED

(San Jose Sciale: Régulations)!

Dr. C. 'J. Brie jer; Director of' Netherlands. Phy.topathological Service advises that the following regulations to safeguard Dutch nurserieg and other holdings againgt the San Jose Scale (Aspidiotus perniciosus Comst.), have beon lssued in a Royal Decree of September 2, 1950.

1. "In this order "live woody plants" "Includes parts thereof, except fruits and seeds and, if not fit for propagation, cut floweris."

2. Each consigiment of imported live woody plants shall be accompanied by two copies of a certificate issued by a competent authority in the country of origin af:ter an ingpection of the consignment which the inspector has found, to the best of his knowledge, to be free from the San jose scale.

3. After arrival in the Netherlands live wojy plants of the genera. Aoer, Crataegus, Cydonia, Malus, Prunus, Pyrus, Ribes, Sorbus and Ulmus shali be treated $\mathrm{ith}$ hydr joctic acid by the Netherlands Phytopathological service; "The consignee shall pay such fer as may be determined:

4. The importation and trangit of live woody nursery stock; except Conifers, is prohibited from the first day of April to the first day of October. They may be imported or conveyed in transit under a license issued by the Director of the Netherlands Phytopathological Service.

5. This Order shail1 come into opere.tion on the $14 t$ h day of September 1950.

The following certificate form was drafted in accordance with the recommendations of the Conference on Plant Quarantine Regulations held in the Hague Apri1.26 - May 2, 1950. Form EQ-375 apparently can be used to furnish all tho-required information. 
PHYTOPATHOL $\cong$ ICAL SERVICE OF (Country)

CERTIFICATE OF HEALTH FOR PLANTS AND PLANT PRODUCTS

This is to certify

that the plants, parts of plants or plant products described below or representative semples of them were thoroughly examined on (dete) . . . . . by (name) ...... ...... an authorized officer of the (service) ...... ................... and were found to the best of his knowledge to be substantially free from injurious diseases and pests; and thet the consignment is believed to conform with the current requirements of the importing country.

\section{(aigna turej)}

(stamp of the service) (rank)

Date, place and neture of disinfestation treatment (if eny): Additional declarations (if any):

\section{DESCR IPTION OF THE CONSIGNMENT}

Name and address of exporter:

Name and address of coneigneo:

Number and description of packagea:

Distingulohing marks:

Quentity and name of produce:

Botanic name:

Origin:

Meens of conveyance:

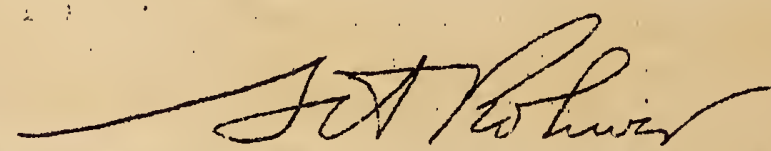

Acting Chief, Bureau of Entiomology and Plant Quarantine 